\title{
Improving Tamil Writing Skills by Using the Four-Phase Technique
}

\author{
Ilangkumaran S/O Sivanadhan", Shoveena Priya D/O Thiagu \\ Department of Modern Languages, Faculty of Language and Communication, Sultan Idris Education University, Tanjung Malim, \\ 35900 Perak, Malaysia
}

Received June 20, 2020; Revised November 10, 2020; Accepted November 26, 2020

\begin{abstract}
Cite This Paper in the following Citation Styles
(a): [1] Ilangkumaran S/O Sivanadhan, Shoveena Priya D/O Thiagu, "Improving Tamil Writing Skills by Using the Four-Phase Technique," Universal Journal of Educational Research, Vol. 8, No. 12A, pp. 7205 - 7210, 2020. DOI: 10.13189/ujer.2020.082501.
\end{abstract}

(b): Ilangkumaran S/O Sivanadhan, Shoveena Priya D/O Thiagu (2020). Improving Tamil Writing Skills by Using the Four-Phase Technique. Universal Journal of Educational Research, 8(12A), 7205 - 7210. DOI: 10.13189/ujer.2020.082501.

Copyright $\odot 2020$ by authors, all rights reserved. Authors agree that this article remains permanently open access under the terms of the Creative Commons Attribution License 4.0 International License

\begin{abstract}
The aim of this study is to analyze and improve the essay writing skills of form 4 students by using the Four-Phase Technique. This study identifies problems faced by students cum respondents and then improvises their essay writing skill with the use of the Four-Phase Technique. The researchers have used a combination of both qualitative and simple quantitative method in this study. This study was conducted in a secondary national school located in Hutan Melintang, Perak. A total of ten students cum respondents were involved in this study. Study tools included questionnaires, interviews, pre-tests and post-tests. Special activities were carried out for six weeks to improvise the essay writing skill of the respondents. The result of a comparative analysis of pretest and post-test shows that the respondents gained an average mark of $80-100$, compared with their previous average marks of 40-59. Hence, this study proves that the Four-Phase Technique has helped to improve the essay writing skill of the students.
\end{abstract}

Keywords Writing Skills, Secondary School, Four-Phase, Education, Essay, Tamil Language

\section{Introduction}

"Education in Malaysia is an ongoing effort towards further developing the potential of individuals in a holistic and integrated manner, so as to produce individuals, who are intellectually, spiritually, emotionally and physically balanced and harmonious, based on a firm belief in and devotion to God. Such an effort is designed to produce Malaysia citizens who are knowledgeable and competent, who possess high moral standards and who are responsible and capable of achieving a high level of personal well-being as well as being able to contribute to the betterment of the family, the society and the nation at large" (Education Act 1996 (Act 550)). The purpose of learning Tamil in form four is to continue providing students with positive proficiencies in Tamil, along with an integrated focus on grammar and continued practice of the four important skills which are listening, speaking, reading and writing (Ponniah, Kumar, Moneyam \& Sivanadhan, 2019; Ponniah, Sivanadhan, Kumar \& Nadarajan, 2019).

Writing skills are considered more important to students than the other three skills which are listening, speaking and reading (Demaisuria \& Muniisvaran, 2019; Shalini, 2018). Writing skill helps students to explain the simple content from what they have read or heard, and it helps them to summarize the main points and explain key details in of a story, text or plot. Writing skills also helps them to express and respond to opinion and common feelings such as happiness, sadness, surprise or interest in the story or text (Nagagothi \& Muniisvaran, 2020). Additionally, the language competency of a student is verified based on their writing skills during an examination. The Four-Phase Technique is considered essential in $21^{\text {st }}$-century writing skills (Vasantakumaran, 2020; Ramesh Raaj, 2020, Mageswary, 2020). The 
Four-Phase Technique consists of the Need Phase, Attention Phase, Visualization Phase and Action Phase. These Four Phases involves the process of engaging students with the class environment and enthusiasm (Utami, 2010).

The Four-Phase Technique gives provides a more tangible solution to students who face challenges in writing. First, is the Attention Phase. This phase seeks to secure the attention of the students through oral composition or opinion sharing in class, in order to assist them in gathering ideas and points speedily. Second is the Need Phase. The needs phase encourages students to counter check their ideas, and identify if the points and ideas are relevant to given topic in the classroom. Students are encouraged to discuss their views, where students who are divided into groups are required to note their ideas or points on the board, and other groups are requested to discuss and revise the mistakes (Pramusinta, 2009). The third phase is the Visualization Phase. This phase encourages students to practice brainstorming and then combine their ideas into cooperative writing. The fourth and final phase is known as the Action Phase. This phase involves direct writing guidance using variable styles in Tamil essay writing. The Four-Phase Technique is designed to help students to organize their ideas of writing clearly and coherently in Tamil. Moreover, at the end of the four steps, students will be self-reliant and confidence in their writing (Yok, 2012). The objective of this research is to identify the reasons behind the problems faced by the students cum respondents and to improvise their essay writing skills with the use of 'Four Phase' method.

\section{Problem Statement}

In this research, writing problems among form four students were identified through pre-test, interview, questionnaire and observations. It was identified that students faced difficulty in expressing their ideas or points in sentences, elaborating on ideas, providing an explanation in different paragraphs, forming correct sentences, providing cohesive and coherent information, spelling accurately and using correct idioms according to the given topic.

The students had very low writing skills. Moreover, the allocation for the Tamil language is only one or two periods per day. It is challenging to teach the skillset defined in the curriculum (Shanmugam \& Balakrishnan, 2020). In relevance to this research, it is challenging to teach essay writing skills in a detailed manner. Students are largely assessed based on their writing skills. Students generally face glitches to express relevant ideas or points to the topic given. Due to the lack of language skills, students hesitate to put forward their ideas which are appropriate to the given topic, and also describe their pro-conceptions, in addition to facing difficulties is giving suitable examples and elaborations to the ideas given
(Thamburaj \& Ponniah, 2016; Ponniah, Thamburaj \& Samuvel, 2017).

Through this research, it was observed that the mentioned problems were caused by five main reasons which are because teachers do not use interesting materials such as media or techniques in their teaching, some students dislike writing essays as they think it is difficult for them, uninteresting essay topics making students dislike essays, students are not able to elaborate ideas leading them to give up and some students despise writing long essays (Kanesan \& Ilangkumaran, 2019; Kumanan \& Periakka, 2019).

Furthermore, during Tamil lessons, teachers do not use interactive media to improve the students writing skills and as a result students do not participate actively during lessons. The current generation of students generally finds it boring to learn in accordance with the traditional teaching methods practiced by teachers (Shanmugam \& Balakrishnan, 2019).

\section{Research Methodology}

This study was conducted in a national secondary school located in Teluk Intan, Perak. Ten students from form four were selected as respondents for this study. For this study, the problems faced by students in writing essays were identified through pre-test, interview, questionnaire, essay activities and post-test. In the pre-test, an essay topic was given to the students and the students were requested to write the essay without any guidance from the teacher. It was observed that students faced difficulty in producing their ideas in an appropriate manner, students could not construct grammatically correct sentences, use suitable words and punctuation and use idioms accurately. From the problem observation, it was deduced that the students had very low writing skills. Thereafter, the students cum respondents were interviewed through a questionnaire during the lesson, where students were requested to state their actual problem in terms of writing essays.

After the problem was determined, a wide range of special activities was planned and executed for six weeks based on the Four-Phase method in order to improvise the essay writing skill of the respondents. A Four-Phase Technique is a teaching technique that divides learning activities into four phases: Need Phase, Attention Phase, Visualization Phase, and Action Phase (Hayas \& Ross, 1975).

The respondents were divided into three different groups. An essay topic was provided to the respondents and they are requested to discuss their essay ideas. The respondent gathered their idea through different media such as books, the internet, news, pictures, and articles, among others. Thereafter, the respondents were encouraged to share and discuss their idea by using the 
One-Stay Two-Stray Technique. This is one of the techniques which support cooperative learning by emphasizing interactions among students between groups in a classroom. Fulfilling the essentials of the Attention Phase, in this activity, members of a group is allowed to strays and move around to others groups to collect ideas from other group and finally come back to their own group and discuss ideas which are gathered. This activity encourages the active participation of students as respondents can move freely to gather ideas and learn new things through collaboration with their classmates (Jusoh, 2014).

The respondents noted the points shared and returned to their groups for further discussion. After returning to their groups, the respondent rechecked their ideas and finalized the points based on need, in accordance with the Need Phase. In this phase, students ensured that their points were relevant to the topic given. Respondents are requested to discuss with their group members and reconstruct the points that they collected from other groups (Daisy, 2003).

Thirdly, in the Visualization Phase, students are encouraged to present their ideas to the front of the class visualizing their based on their own imagination and experiences of life in accordance with the essay topic given. Students are encouraged to use mind map models, to visualize their ideas in point form, or rather translate what's in their mind into a visual picture. Through the visualization phase, respondents are able to organize and understand information faster and better. This phase not only boosts creative thinking but also enables the respondents to become more productive and efficient in terms of understanding the topic of the essay and the relevant points.

Finally, in the Action Phase, respondents are required to write their essays clearly and confidently without any burden of making mistakes, after the essay topic was discussed thoroughly in the class, inclusive of feedback from the teacher and peers.

The respondents are recommended to adopt the Four-Phase Technique as it provides a solution to writing difficulties. By utilizing the Four-Phase Technique, respondents are able to focus on the essay topic with higher attention, understand the needs and requirements of the essay topic, visualize the whole process of essay writing in the mind and adapt it to the paper, and finally write their essay more confidently in the action phase. The Four-Phase Technique also helps students to organize their ideas of writing clearly and coherently after getting feedback from teachers and group members.

In this classroom action research, the researcher has used two techniques to collect qualitative and quantitative data. Essays tests were used to collect quantitative data in this research whereas interviews and questionnaires were used to collect qualitative data. The results of the essay test where analyzed in order to prove whether the implementation of the Four Phase-Technique helped students to improve their writing skills.

It was observed that students were engaged when the Four-Phase Technique was implemented during Tamil lessons, and thus it was successfully able to grab the attention and interest of the respondents, and as a result, students who faced challenges in writing Tamil, essays were able to get a better idea of the methods of writing essays and write more confidently.

Moreover, the researcher lined up six different essay topics for six weeks, and implemented the plan with different measures and media in accordance with the Four-Phase Technique. The activities were sorted based on the capability of the students and the study was continued for six weeks. The essay writing activities were conducted for 90 minutes after school.

Lastly, the researcher observed the improvement of the students cum respondents for 8 weeks. The researcher approached the respondents personally and interviewed them in regard to the effect of the Four-Phase Technique in terms of writing essays in Tamil (Jamaluddin, 2000). In addition, the researcher interviewed three language teachers and identified the problems faced by students in writing essays. The teacher suggested some of the techniques used by them (Lattao \& Martin, 2020). The research explains the benefits of Four-Phase Technique in essay writing.

\section{Result and Discussion}

A pre-test was done before the implementation of the Four-Phase Technique, and a post-test was conducted after the implementation of the Four-Phase Technique. The results of the pre-test and post-test are able to show the improvement of the students cum respondents after undergoing the Four-Phase Technique to improve their writing skills. The results of the pre-test and post-test are as mentioned in Table 1 and Table 2.

Table 1. Pre-test results of essay writing before implemented the Four Phase Technique

\begin{tabular}{|c|c|c|c|}
\hline Students & Score (100) & $\begin{array}{c}\text { Percentage } \\
(\%)\end{array}$ & Band \\
\hline Student 1 & 40 & $40 \%$ & $\mathrm{C}$ \\
\hline Student 2 & 35 & $35 \%$ & $\mathrm{D}$ \\
\hline Student 3 & 50 & $50 \%$ & $\mathrm{C}$ \\
\hline Student 4 & 42 & $42 \%$ & $\mathrm{C}$ \\
\hline Student 5 & 41 & $41 \%$ & $\mathrm{C}$ \\
\hline Student 6 & 32 & $32 \%$ & $\mathrm{D}$ \\
\hline Student 7 & 52 & $52 \%$ & $\mathrm{C}$ \\
\hline Student 8 & 28 & $28 \%$ & $\mathrm{D}$ \\
\hline Student 9 & 38 & $38 \%$ & $\mathrm{D}$ \\
\hline Student 10 & 35 & $35 \%$ & $\mathrm{D}$ \\
\hline Average Score & $\mathbf{3 9 3}$ & $\mathbf{3 9 . 3 \%}$ & $\mathbf{5 C , 5 D}$ \\
\hline
\end{tabular}


Table 2. Post-test results of essay writing after implemented the Four Phase Technique

\begin{tabular}{|c|c|c|c|}
\hline Students & Score (100) & Percentage (\%) & Band \\
\hline Student 1 & 85 & $85 \%$ & $\mathrm{~A}$ \\
\hline Student 2 & 86 & $86 \%$ & $\mathrm{~A}$ \\
\hline Student 3 & 90 & $90 \%$ & $\mathrm{~A}$ \\
\hline Student 4 & 89 & $89 \%$ & $\mathrm{~A}$ \\
\hline Student 5 & 93 & $93 \%$ & $\mathrm{~A}$ \\
\hline Student 6 & 95 & $95 \%$ & $\mathrm{~A}$ \\
\hline Student 7 & 98 & $98 \%$ & $\mathrm{~A}$ \\
\hline Student 8 & 80 & $80 \%$ & $\mathrm{~A}$ \\
\hline Student 9 & 86 & $86 \%$ & $\mathrm{~A}$ \\
\hline Student 10 & 87 & $87 \%$ & $\mathrm{~A}$ \\
\hline Average Score & $\mathbf{8 8 9}$ & $\mathbf{8 8 . 9 \%}$ & $\mathrm{A}$ \\
\hline
\end{tabular}

The results show that the undoubtedly prove that there is a big improvement in terms of essay writing in Tamil after the implementation of the Four-Phase Technique. The pre-test results show that students generally secured a low score in essay writing. It can be seen that the average score was 39.3. The overall bands obtained by the students were $5 \mathrm{Cs}$ and 5Ds. It was observed that the students writing skills were very low. The students score was lower than the passing score of 60 to 70 percentage. Research shows that students faced many challenges in writing Tamil essay according to the correct method and format. Students also failed to come up with a reasonable writing plan, relevant to the given topic. The pre-test data showed that students repeated the same points over and over again. Most of the students were not able to come with relevant points and although some of the students had relevant ideas, they were not able to construct their ideas clearly in a paragraph. The pre-test data results also show that students were not able to organize their ideas, use appropriate grammar, relevant words, and correct punctuation in addition to using idioms accurately.

After the implementation of the Four-Phase Technique in writing an essay, the researcher observed that there were still students who made errors in using idioms to elaborate their points. At the end of the Four-Phase Technique activities and after understanding the feedback from group discussions, students who faced problems with idioms and spelling words, scored better in the post-test compared to the pre-test. Students were able to provide accurate ideas and points according to the topic given after collaborative learning among the respondents. The post-test average score of the respondents was also better than the pre-test average score. From the improvement, it is seen that the Four-Phase Technique can improve the writing skill of the students through the activities in each phase. Practicing the Need Phase, Attention Phase, Visualization Phase, and Action Phase were able to improved students ability in essay writing in
Tamil according to their essay topics. This idea is supported by the theory proposed by Carnegie (1971: 228). He states that a four-phase technique brings improvements toward the students" imaginative writing skills as it uses a process approach in teaching writing where the assessment in a form of a portfolio. Furthermore, he mentioned that the Four-phase Technique can give better solutions to problems faced by students in Tamil essay writing.

Table 2, it proved that the implementation of the Four-Phase Technique has improved students writing skills and provide a more conducive learning environment. The improvements were also observed during the Four-Phase Technique learning activities after school. Before the implementation of the Four-Phase Technique, the researcher found that students did not focus throughout the essay writing lesson during the Tamil period. But after implementing the Four-Phase Technique, there was improvements in writing skills. The students were more active, and focused on learning new methods of essay writing, with rejuvenated interest. Through the pre-test results, activities during the lessons and post-test results, it is proven that the Four-Phase Technique was able to improve essay writing skills in Tami through two-way learning and active participation. The Four-Phase Technique allows students to interact and observe each other through collaborative learning. This technique not only encourages students to have well-written paragraphs in essays but also help produce more comprehensive essays in according to the topic given.

As a result, the score of students in essay writing has increased. The Four-Phase Technique facilitated students to gather information from multiples angles and approaches. After a variety of activities were conducted during the lessons for 6 weeks, students identified the problems in essay writing and corrected their flaws in essay writing methods. With the post-test results, the researcher found that the students able to write the ideas clearly and confidently. In addition, the students wrote excellent ideas and examples in Tamil essay writing. In post-test, it was shown that the students got a high score in essay writing. It can be seen that the average score was 88.9. All the students managed to score an A for the post-exam making the total band for the post-test as 10A. It shows that the students had a very good improvement in writing skills.

\section{Conclusion and Suggestion}

Based on the research above, it can be concluded that the implementation of the Four-Phase Technique was able to improve students' Tamil essay writing skills. The study found that, the students problems were addressed and improvement was observed after the Four-Phase 
Technique was implemented. The implementation of the Four-Phase Technique showed an improvement in how students came up with ideas in accordance with the essay topic and thus, secured a better score during the exams. Pre-test and post-test data were compared and analyzed to find the difference on how the writing skills were improved after the Four-Phase Technique was implemented. In the pre-test, students scored $\mathrm{D}$ and $\mathrm{C}$, but after the Four-Phase Technique was implemented during lessons, students were able to score A in essay writing. The researcher conducted six different methods of approach with their respondents in accordance with the Four-Phase Technique. The Four-Phase Technique had a huge impact on the $21^{\text {st }}$ century essay writing skills. The innovative approaches of $21^{\text {st }}$ century helped students improve their essay writing skills and stimulate a higher level of thinking. The pre-test average score of 39.3 being improved to an average score of 88.9 in the post-test, clearly shows that the implementation of the Four-Phase Technique in Tamil lessons, has undoubtedly improved the Tamil essay writing among the students cum respondents.

\section{REFERENCES}

[1] Carnegie, D. (1984). The Quick and Easy Way to Effective Speaking. London: Kingswood Tadworth Surrey.

[2] Daisy, D. (2003). September 25-27). Using Process approach to enhance guided writing among students of form 2RK. Pulau Pangkor, Perak.

[3] Demaisuria, K., \& Muniisvaran, K. (2019). Analyse physical structure on haiku Na.Patchaibalan [Analisis struktur luaran bahasa ke atas haiku Na.Patchaibalan]. Muallim Journal of Social Sciences and Humanities, 3(3), 371-378. https://doi.org/10.33306/mjssh28

[4] Hayas, D. K., \& Ross, D. M. (1975). The Very Young and Education: 1974 State Activity.

[5] Jamaluddin, M. (2000). Using Process Approach to develop writing skils among form 1 students. Perak: Universiti Pendidikan Sultan Idris.

[6] Jusoh Z. (2014). Meningkatkan kemahiran menulis karangan berasaskan kemahiran bercerita di kalangan pelajar. SMK Selayang. Selangor.

[7] Kanesan, R., \& Ilangkumaran, S. (2019). A study on film adapted from the novel 'Sila Neranggalil Sila Manithargal'. Muallim Journal of Social Sciences and Humanities, 3(4), 475-481. https://doi.org/10.33306/mjssh/37

[8] Kumanan, R., \& Periakka, R. (2019). The role of children's game in developing Tamil language among Tamil school students. Muallim Journal of Social Sciences and Humanities, 3(4), 501-510. https://doi.org/10.33306/mjssh/ 40

[9] Lattao, A. M., \& Martin, M. M. (2020). The Utilization Of
Indigenous Communication Arts Instructional Materials In Teaching Language. Journal of Technology and Humanities, Vol 1(1), p. 18-25.

[10] Mageswary, K. (2020). An analysis of the main finding approach in the comprehension text. Muallim Journal of Social Sciences and Humanities, 4(1), 85-92. https://doi.org/10.33306/mjssh/59.

[11] Nagagothi, A., \& Muniisvaran, K. (2020). Semiotic analysis in the short story illustrations of Kashvi. Muallim Journal of Social Sciences and Humanities, 4(1), 36-41. https://doi.org/10.33306/mjssh/53

[12] Ponniah, K., Kumar, M., Moneyam, S., \& Sivanadhan, I. (2019). The teaching of Thirukkural based on HOTS among the students of Tamil primary schools in the state of Perak. International Journal of Advanced and Applied Sciences, 6(2), 94-101. https://doi.org/10.21833/ijaas.2019.02.014

[13] Ponniah, K., Sivanadhan, I., Kumar, M., \& Nadarajan, P. (2019). Implementation of the 21st century learning in learning and facilitation of Thirukural in Tamil primary schools. International Journal of Advanced and Applied Sciences, 6(1), 43-50. https://doi.org/10.21833/ijaas.2019.0 1.006

[14] Ponniah, K., Thamburaj, K. P., \& Samuvel, S. J., I. (2017). Language attitude among Tamil language teachers. International Journal of Advanced and Applied Sciences, 4(6), 142-147. Retrieved from http://www.science-gate.com /IJAAS.html.

[15] Pramusinta, A. D. (2009). Using A Four-Phase technique to improve the students imaginative writing skills. Indonesia: SMA Negeri Sukoharjo.

[16] Ramesh Raaj, M. (2020). The understanding of vetrumai urubhu among Form Two students. Muallim Journal of Social Sciences and Humanities, 4(1), 79-84. https://doi.org/10.33306/mjssh/58

[17] Shalini, K. (2018). Problems in virtual learning environment on teaching and learning of Tamil language. Muallim Journal of Social Sciences and Humanities, 2(4), 265-276. Retrieved from https://www.mjsshonline.com/index.php/jo urnal/article/view/72

[18] Shanmugam, K., \& Balakrishnan, B. (2019). Designing an ICT guiding framework for science teachers in rural Tamil schools in Perak PPembinaan kerangka panduan ICT bagi mata pelajaran sains untuk guru-guru SJK(T) di luar bandar di negeri Perak]. Muallim Journal of Social Sciences and Humanities, 3(4), 441-458. https://doi.org/10.33306/mjssh/ 34

[19] Shanmugam, K., \& Balakrishnan, B. (2020). Microsoft power point as a presentation tool for teaching and facilitating science in rural Tamil schools in Perak [Perisian microsoft power point sebagai peranti persembahan semasa pdpc sains di SJK(T) luar bandar di negeri Perak]. Muallim Journal of Social Sciences and Humanities, 4(1), 49-65. https://doi.org/10.33306/mjssh/55

[20] Thamburaj, K. P., \& Ponniah, K. (2016). Hierarchical grammatical tagging for tinai (landscape) of cankam Tamil literature. Indian Journal of Science and Technology, 9(S1), 1-4. DOI:10.17485/ijst/2016/v9iS1/97820.

[21] Utami, F. S.. (2010). Improving students writing skills using 
A Four-Phase technique. Indonesia: English Education department Sebelas Maret University Surakarta.

[22] Vasantakumaran, S. (2020). Improve learning of peyareccam by using film technique. Muallim Journal of Social Sciences and Humanities, 4(1), 73-78. https://doi.org/10.33306/mjssh/57

[23] Yok, L. (2012). Using Four Square Technique to develop writing skills among standard two students. Institut pendidikan guru kampus Temengku Bainun. Pulau Pinang. 